\title{
The Role of Quality Practices in Service Organizations
}

\author{
Anders Gustafsson Ph.D. ${ }^{1}$ \\ Lars Nilsson Ph.D. ${ }^{1}$ \\ Michael D. JohnsonPh.D. ${ }^{2}$ \\ ${ }^{1}$ Service Research Center, Karlstad University, Karlstad, Sweden \\ ${ }^{2}$ University of Michigan Business School, Ann Arbor, Michigan, USA
}

\begin{abstract}
Many organizations use quality management to improve firm performance, but the results do not always come quickly. Research in the manufacturing sector has found that different organizational characteristics, such as firm size and the degree of capital intensity, influence the perceived benefits of quality management. Uses data from 281 firms that work with quality management to investigate the role of quality practices in service organizations. The results of our investigations support that the relationship between quality practices and business performance is dependent on firm size. In addition provides insight into how the business results are influenced by individual quality practices such as employee management, process orientation and customer orientation, depending on firm size.
\end{abstract}

Keywords: Quality management, Service industries, Organizations, Empirical study, Sweden 


\section{Introduction}

The widespread interest in using quality management to improve organizational performance started in the manufacturing sector and later spread to service organizations. Quality management can be viewed as an approach to management characterized by its principles, practices and techniques (Dean and Bowen, 1994). Each principle is implemented through a set of practices, which consist of activities such as collecting customer information, improving work processes and managing employees. The practices are, in turn, made effective by the support of a wide array of techniques. The strength of quality management compared with other business philosophies is its focus on practical methodology, i.e. practices and techniques.

There is a substantial body of empirical research that provides support for the notion that quality practices improve firm performance (Lemak and Reed, 2000; Hendricks and Singhal, 1997). In their research on quality award winners, Hendricks and Singhal $(1997,2001)$ find that many different organizational characteristics influence the benefits of quality practice. Examples of such organizational characteristics are firm size and the degree of capital intensity. Hendricks and Singhal (2001) provide empirical evidence that small firms benefit more from quality management then their larger counterparts, in terms of achieving more improvement in operating income and sales. By contrast, Benson et al. (1991) find no significant effect of company size on the practice of quality management. Ahire and Golhar (1996) and Raymond et al. (1998) investigate customer orientation in relation to business process engineering and identify systematic differences between small and large firms. What these studies do not investigate is how the relationship between business performance and certain quality practices vary depending on firm size. Furthermore, the broad-based empirical studies on quality management focus on the manufacturing sector or a combination of manufacturing and service firms, while few studies have investigated the role of the different quality practices in service organizations per se. 
The goal of this paper is to examine quality practices, as operationalizations of three quality principles: employee management, process orientation and customer orientation, as well as their role in creating satisfied customers and improved business results. We use data from the Swedish Business Excellence Index (SBEI) to examine the effects of quality practices on business performance. Altogether, our sample consists of 281 service organizations that, to a different extent, work with quality management. The results of our investigation show how the relationship between business performance and certain quality practices vary with firm size. For instance, process orientation has a direct impact on customer satisfaction for large organizations, while this effect is not evident for small service organizations. The implications of the results will be discussed in greater detail in the last section of our paper.

\section{A framework for quality practice}

A quality management concept is essentially a business philosophy or a company ideal (Kohli and Jaworski, 1990). Hellsten and Klefsjo“ (2000) view total quality management as a management system consisting of core values, techniques and tools, while Hackman and Wageman (1995) use core values and interventions (structures, systems and/or work practices) as their building blocks. Both these sets of building blocks can be used to describe what quality management really is, but they do not fully capture the whole range of activities present in quality management.

Quality management is better viewed as a combination of principles, practices and techniques (Dean and Bowen, 1994). To be able to compare industry sectors, organizations and even individuals, the object of comparison must be the practices, i.e. the activities performed to display and embody the principles of quality management. The proposed framework we have used in this paper comprises three general areas for consideration: quality practices, customer satisfaction and business results. What 
quality practices consist of varies in the literature. Consequently we have to explain how we have interpreted them in this paper.

According to Dean and Bowen (1994) most of what has been written about quality is based on three principles: customer focus, continuous improvement and teamwork. Other advocates of the quality movement include more principles in their conceptualizations of quality management. For instance, Dahlgaard et al. (1998) include five principles of quality management:

(1) management commitment;

(2) focus on the customer and the employee;

(3) focus on facts;

(4) continuous improvement; and

(5) everybody's participation.

Quality awards, or so-called excellence models, are built on a large number of values, similar to the underlying principles in the quality movement. For instance, the Swedish quality award has 13 core values which are: customer orientation, committed leadership, everybody's involvement, long-term focus, community responsibility, process orientation, education and training, proactiveness, continuous improvement, benchmarking, responsiveness, decisions based on facts, and cooperation. In other words there are too many variations of underlying principles in quality management for them all to be tested in one study. In this investigation we have chosen to focus on the practices of three core principles of the quality movement: employee management, process orientation and customer orientation. These practices are included in every description of different quality principles given their central role in the quality movement. Furthermore, they span several dimensions of the concept of quality management.

In Figure 1 we illustrate the framework and model for quality practice as used in this study. The model consists of the previously described variables. These are operationalized through a number of concrete questions at an organizational level as can be seen from Table I. For instance, employee 
management is operationalized by improvement of employee satisfaction and the involvement of employees in the development of the business, aimed to capture the quality of employee management within an organization. The basic assumption of quality researchers is that employee satisfaction and commitment are needed to support process and customer orientation as suggested in the model in Figure 1 (Hackman and Wageman, 1995). We also posit a direct effect of employee management on business results. This is consistent with prior research that suggests a direct relationship between job satisfaction and company performance (laffaldano and Muchinsky, 1985). This effect captures a variety of factors which include, but are not limited to, increased employee education and competence, employee productivity and teamwork and increased commitment and loyalty (decreased turnover).

Process orientation is operationalized through the practices to first identify and document, and later to start measuring, evaluating and improving the core processes of the organization. A process is a set of activities that, when completed together, produce a result of value to a customer (Ittner and Larcker, 1997). A process is therefore a structure for action, the structure by which an organization does what is necessary to produce value for its customers (Davenport, 1993). There is a wide range of process management mechanisms, from process-focused improvement tools (such as process value analysis and process cycle time analysis) to the implementation of organizational structures that are based on core business processes (Ittner and Larcker, 1997).

Frei et al.'s (1999) study of the impact of process variation on financial performance in financial service institutions sheds further light on the dynamics of the influence of process orientation on customer satisfaction. Frei and his co-authors identify a lack of rigorous policies and processes as one important factor contributing to the substantial variation in service delivery. An improvement in operations can reduce the apparent variation in the process, and have an indirect effect on business results through increased customer satisfaction. Overall, this suggests that while process orientation, 
like employee management, supports a firm's customer orientation, process orientation can also have a direct effect on customer satisfaction.

In marketing, a market orientation has been defined as the organization wide generation of market intelligence, dissemination of the intelligence across departments and organization-wide responsiveness to this diffusion (Kohli and Jaworski, 1990). Narver and Slater (1990) argue that a fullblown market orientation also includes a competitor orientation. However, our focus is on a firm's more specific customer orientation. Customer orientation emphasizes an organization's ability to attain customer information, to analyze it and set priorities for improvement, and use these priorities to drive product and process change (Johnson, 1998; Johnson and Gustafsson, 2000). By gaining a better understanding of customer needs and the use of this knowledge to design better products and services, customer orientation should have a direct impact on customer satisfaction.

As can be seen from Figure 1, we expect internal quality processes related to process and customer orientation to impact business results largely through their impact on customers, or customer satisfaction. Customizing a product to meet or exceed the needs of a heterogeneous population of customers increases customer satisfaction, which in turn increases profitability. The core operations within our process orientation construct are those which support an organization's customer orientation.

Research that links customer satisfaction to other business measures usually defines satisfaction as a customer's overall evaluation of the consumption experience (Johnson, 2001). Previous research on customer satisfaction demonstrates a positive impact of satisfaction on both market value and accounting returns (Anderson and Fornell, 1994; Ittner and Larcker, 1996).Because of a "front loading" of customer costs and a "back loading" of revenues over the course of one's relationship with customers, satisfied and loyal customers are more profitable (Johnson, 1998; Edvardsson et al., 2000). Thus there is a direct relationship in Figure 1 between customer satisfaction and business results. 
Essentially, business results can improve in two ways: through increased revenues or reduced costs. Quality practices can be implemented to achieve both of these goals (see, e.g. Bergman and Klefsjo“, 1994; Johnson and Gustafsson, 2000). Improvements in internal quality may increase productivity and lower internal costs, thereby increasing profitability indirectly. Customizing a product to exceed the needs of the customer can increase customer satisfaction, which in turn has a direct effect on customer loyalty and retention, and thereby increases future sales.

\section{Research methodology}

Due to the fact that quality management is a potentially unified business strategy, many of the quality practices used in organizations are strongly correlated with one another. As a result, multicollinearity can obscure the relationships between practices and performance. Structural equation modeling is well suited to handle such situations (Steenkamp and van Trijp, 1996). We use partial least squares (PLS), a causal modeling method that is particularly well suited to operationalize quality-related models such as the one illustrated in Figure 1 (Gustafsson and Johnson, 1997). PLS is an estimation procedure that integrates aspects of principal-components analysis with multiple regression (Wold, 1982). The procedure essentially extracts the first principle component from each subset of measures for the various latent variables and uses these principle components within a system of regression models. The algorithm then adjusts the principle-component weights to maximize the predictive power of the model.

In order to test for differences between small and large service organizations, two separate versions of the model in Figure 1 were estimated, one for small and one for large service organizations. All constructs were modeled using reflective indicators (i.e. the indicators are created under the perspective that they all reflect the same underlying phenomenon (Chin, 1998)). To evaluate the significance of the paths in the two models of jackknife estimates were generated (Chin, 1998). The general approach of jackknifing is to delete every nth case or observation, estimate the model 
parameters and repeat this sample-re-sample procedure to generate a set of standard errors for the model parameters (Efron and Tibshirani, 1993). Simple t-statistics are then computed to determine whether the parameters are different from zero and different from model to model. Following Tukey's guidelines, 5 percent of the sample was removed during the re-sampling procedure resulting in 20 subsamples per model.

\section{Survey instrument}

The survey instrument was a four-page mail survey sent to the chief executive officer (CEO) in different Swedish organizations in the competitive sector during November 1999. The survey instrument was developed following the EFQM Excellence Model and included 51 items. Each item was scored on a tenpoint scale ranging from "completely disagree" to "completely agree" (except for a section containing background variables for categorizing the organization). For the purpose of this study 17 items were used to operationalize the latent constructs, 11 for the three internal quality constructs and six for the two performance constructs (see Table I).

As shown in Table I, employee management is operationalized as a five-item construct, while both process and customer orientation are three-item constructs. Our constructs for business results and customer satisfaction are measured indirectly by asking the management of the participating organizations. Subjective measures of performance are commonly used in research of companies and business units of large companies (Powell, 1995). In this study we use a two-item construct to measure customer satisfaction and a four-item construct to measure business results.

Our primary analysis is based on self-reported company measures for all of our constructs, both internal and external to the organization. Measuring management perception of quality practices on a ten-point Likert-scale captures the perceived extent of quality practice in the organization. Our belief is that the CEO in each organization is the individual who is best suited to answer a survey that covers both 
quality practice and business results. It is also an accepted research approach and works quite well for organizations that are not too large. In this case the number of really large firms is limited, we define large has having 50 or more employees.

\section{Firm sample}

In the SBEI for 1999, 1,658 organizations participated. The response rate for this mail survey was 26 percent, a level that is typical for this kind of study (Frohlich, 2002). An investigation of some of the organizations that chose not to participate in this study revealed that they did not adhere to a systematic quality strategy, while other organizations did not feel that they had time to participate in this kind of survey.

The focus of this investigation is on service organizations belonging to NACE 70-99. This includes organizations working with real estate activities, education, health care, research and development and computers. The organizations in our sample are also categorized according to firm size in two classes, small and large organizations. The limit between a small and large firm was set at 50 employees. Our sample of 281 firms was divided in 159 small and 122 large organizations.

\section{Results}

The proposed model was estimated using PLS across individual firms separately for small $(n=159)$ and large $(n=122)$ service organizations. We first discuss the quality of the measurement models and then examine the latent variable model results.

The first step in assessing the measurement models involves testing the reliability of each measured variable to ensure that the measurement variables (MVs) apply accurately to their related constructs. Overall the MV loadings are all relatively large and positive. As can be seen in Table I, in the model for small service organizations, all the loadings exceed the recommended threshold value of 
0.707 (Hulland, 1999), while 16 of the 17 loadings in the model for large service organizations exceed the threshold value. The exception is the loading for the fifth item in the employee management construct (loading EM_5 $=0.661$ ). The research practice is, however, to keep the item in the analysis if the loading exceeds 0.5 if there is a good theoretical reason to do so. In this case the item is retained in the analysis in order to keep the models directly comparable.

The models for small and large service organizations explain 45 percent and 37 percent of the variation in business results respectively, as well as 30 percent and 24 percent respectively of the variation in customer satisfaction. Of the 14 paths in the two estimated models, 12 turn out to be significant (using adjusted t-tests and $\mathrm{p}<0.05$ ). The two exceptions are for the model for small services, where the paths between process orientation and customer orientation, and process orientation and customer satisfaction are not significant, see Figures 2 and 3.

The jackknife estimates also allow us to test whether the parameters are significantly different between the two models, the results of which are presented in Table II. Of the seven paths that are directly comparable between the two estimated models, there is a significant difference in five of them. The two exceptions are the relationships between employee management and process orientation, and between employee management and business results. To summarize, the effects of employee management on customer orientation, customer orientation on customer satisfaction and customer satisfaction on business results are larger for small service organization. In contrast, the effects of process orientation on customer orientation and customer satisfaction have a larger value for large service organizations.

\section{Discussion and conclusions}

The estimation of the two different models reveals systematic differences concerning quality practices for service organizations. When comparing the estimated paths in the two models, it becomes evident 
that the effect of quality practices varies depending on the size of the service firms. In small organizations, customer orientation seems to be relatively more important, while process orientation seems to be relatively more important for large service organizations.

Often large organizations are described as more advanced in quality management compared with smaller organizations, which then is used to explain why large organizations gain higher effects for their quality efforts. Studying the mean values of the individual statements used to measure the quality practices no such differences can be found (see Table II). There are no statistical differences between the two samples regarding quality practices. The only significant difference that can be found is for one of the questions that is included in the customer satisfaction variable; customer complaints. It seems that the number of customer complaints is lower for small organizations compared with their larger counterparts. So the identified differences between small and large service organizations are not attributed to the notion that these organizations are at different quality levels. Rather, the differences are more like due to organizational size per se.

One interpretation of this is that small and large firms have different characteristics that will force them to implement and use quality management differently from each other. As a consequence, different quality practices will have different effects depending on organizational size. As described in more detail below, almost by definition large service firms must pay more attention to those processes that allow an organization to be efficient and effective. Put differently, process orientation does not even become a relevant concept unless a firm is large enough for it to be a problem.

Customer satisfaction has a larger impact on business results for smaller companies compared with larger companies, which implies that pleasing the customer is more immediately important for the small organizations. It makes sense to think that the smaller organizations are more dependent on a stable customer base consisting of customers that return to the same supplier. A larger organization is more likely to attract and keep customers with a good systematized service, i.e. a service that is 
delivered through a good sound process. The smaller organizations, on the other hand, are likely to customize more and are more reliant on their employees. The finding that the impact of employee management on customer orientation is weaker for the larger organizations is consistent with this argument.

Ahire and Golhar (1996) noted that smaller organizations are more customer oriented, but this research also points out that customer orientation is more profitable for smaller organizations. As a consequence of the discussion on customization, having knowledge of customer expectations and customer needs is a prerequisite to succeed with such a strategy. It seems like small organizations are in a better position to benefit from this knowledge due to the more individualized nature of services in small service organizations. This argument is supported by Hendricks and Singhal (2001) who conclude that one of the reasons why small firms are more successful with quality management is that they are in a better position to gain an understanding of key customer needs, and transfer and share organizational learning more effectively.

As noted, process orientation plays a much weaker role as a quality practice in small service organization compared with large ones. The production process is visible to service customers, as indeed they are part of the process, and process orientation has a direct impact on customer satisfaction with large service organizations. This effect is not significant for small services, which are believed to depend on processes that do not need to be as complex, and which only a few persons are involved in service production. A business process framework provides both the structural form and an integrated organizational approach to transform and communicate customer needs into actions by the employees in an organization. For large service organizations, process orientation creates a framework by which a customer orientation can be operationalized or built on. But for small services, the role of process orientation is less obvious while the role of customization or direct customer orientation is more 
obvious. As a result, process orientation does not even become relevant until the organization grows in size.

It is interesting to find that employee management is equally important for both small and large service firms. Since the customers' perception of a service is highly dependent on the frontline employees, the personnel are often described as the company's key resource. Our research supports that notion. Particularly for a service organization, it is important to design attractive jobs and a stimulating environment, to offer training and education and to organize the recruitment, training and developing of staff. Through training and genuine concern for employee welfare, the organization can improve the performance of the organization.

One contribution of our study is that it provides managers with a framework for understanding how quality processes affect each other and organizational performance. The framework is useful on two different levels: an industry level and a company level. At the industry level, the framework helps us to understand the linkages between practices and performance and provide theoretical explanations as to why a certain practice may work well in one context but not another. At the company level, the framework can be used to evaluate how different quality improvements are linked to customer satisfaction and business performance.

This study was conducted in Sweden with a sample of Swedish firms. One question to ask is: "are there any cultural differences concerning quality practices that would influence the interpretation of the results of our study?" In a cross-cultural quality management study of 12 countries, the USA, Japan and Sweden are on the same high level with respect to their cultural approach toward quality management (Kroslid, 1999). These countries were considered more advanced than other countries such as Korea and China. This makes Sweden a good context for investigation. However, it is still important to conduct a cross-cultural study that investigates differences in the relationship between quality practice and performance going forward. 
One of the main conclusions and the managerial implication of this paper is: while large service organizations should focus more attention on reducing variation in the production process, customer orientation is the most important quality practice for small service organizations. Since the relationship between quality practices and business performance is dependent on firm size, the quality strategy of an organization must change when an organization grows. 


\section{Figures}

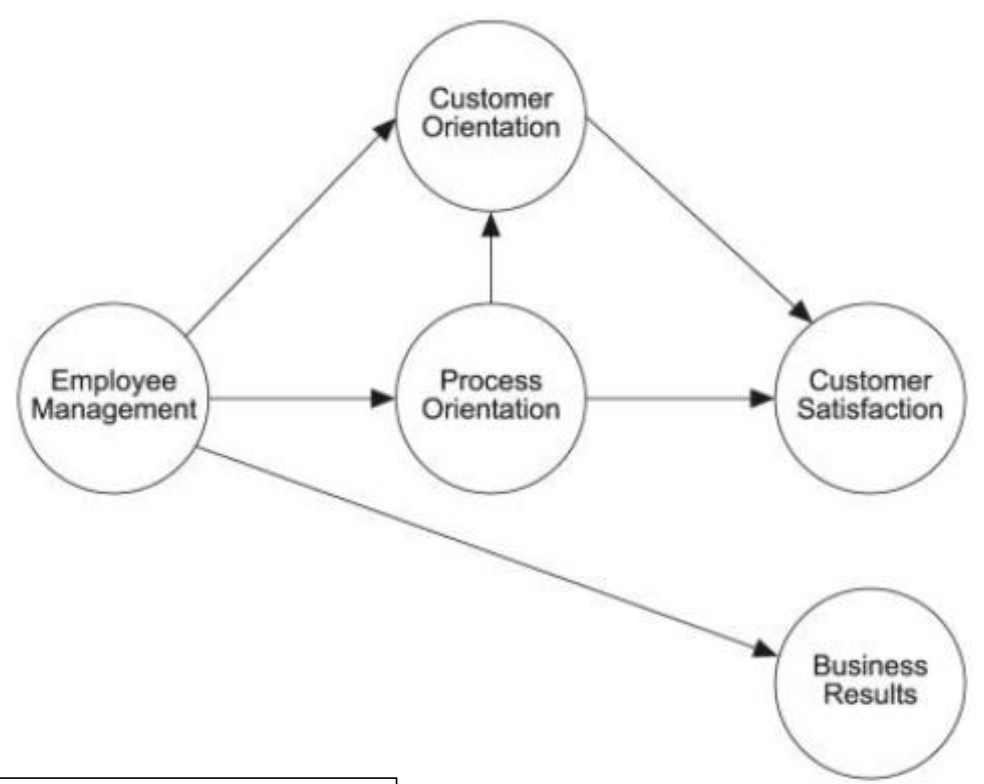

Fig.1 


$\begin{array}{cc}\text { Small } & \text { Large } \\ \text { organizations } & \begin{array}{c}\text { organizations } \\ \text { Mean Loading }\end{array} \\ \text { Mean Loadings }\end{array}$

Mean Loading Mean Loadings

EM_1 The competence of employees is maintained and developed in a systematic way

EM_2 The employees participate systematically in the

EM_3 The factors that have a positive impact on

$\begin{array}{llll}64.85 & 0.809 & 62.87 & 0.850\end{array}$

EM_4 There are goals for employee satisfaction, loyalty,

EM_5 $\quad$ Employee satisfaction is analyzed and the|results

\begin{tabular}{llllll}
\hline are the target of continuous improvement & 72.26 & 0.815 & 69.76 & 0.661
\end{tabular}

$\begin{array}{llll}57.42 & 0.853 & 55.90 & 0.782\end{array}$

$\begin{array}{llll}59.06 & 0.871 & 62.92 & 0.838\end{array}$

$\begin{array}{llll}73.52 & 0.790 & 69.92 & 0.746\end{array}$

$\begin{array}{llllll}\mathrm{PO} & \text { Core processes are identified and documented } & 71.71 & 0.871 & 73.52 & 0.885\end{array}$

$\begin{array}{llllll}\mathrm{PO}_{2} 2 & \text { The core processes are measured and evaluated } & 63.94 & 0.922 & 62.46 & 0.903\end{array}$

PO_3 Co-workers are continuously stimulated and motivated to participate in development and improvement of the core processes

CO_1 The factors creating customer satisfaction are clearly defined

CO_2 There are systematic goals for customer

$\begin{array}{llll}68.60 & 0.888 & 65.31 & 0.898\end{array}$

satisfaction, loyalty and complaints

CO_3 Analysis of customer satisfaction is made and the results are followed by continuous improvements

CS_1 During the last years, customer satisfaction has increased

CS_2 During the last years, customer complaints have decreased

BR_1 During the last years, business result has improved

BR_2 During the last years, the effectiveness of the organization has improved

BR_3 During the last years, the use of resources has improved

BR_4 During the last years, business result has improved compared with similar businesses

$\begin{array}{llll}74.28 & 0.848 & 74.75 & 0.821\end{array}$

$\begin{array}{llll}67.30 & 0.915 & 66.89 & 0.867\end{array}$

$\begin{array}{llll}67.59 & 0.873 & 70.42 & 0.847\end{array}$

$\begin{array}{llll}74.50 & 0.934 & 72.65 & 0.906\end{array}$

$\begin{array}{llll}71.26 & 0.862 & 64.51 & 0.867\end{array}$

$\begin{array}{llll}75.89 & 0.732 & 78.20 & 0.841\end{array}$

$\begin{array}{llll}76.73 & 0.892 & 79.75 & 0.886\end{array}$

$\begin{array}{llll}70.90 & 0.854 & 74.43 & 0.803\end{array}$

$\begin{array}{llll}72.15 & 0.832 & 73.13 & 0.733\end{array}$

Notes: $\mathrm{CS}=$ Customer satisfaction, $\mathrm{BR}=$ Business result, $\mathrm{EM}=$ Employee management, $\mathrm{PO}=$ Process orientation, $\mathrm{CO}=$ Customer orientation

Fig.2 


\begin{tabular}{lcccc} 
Effect of & On & $\begin{array}{c}\text { Small services } \\
\text { (impact) }\end{array}$ & $\begin{array}{c}\text { Large service } \\
\text { (impact) }\end{array}$ & $\begin{array}{c}\text { Significant difference } \\
\text { between the models }\end{array}$ \\
\hline EM & PO & 0.681 & 0.601 & $\mathrm{~ns}$ \\
EM & CO & 0.596 & 0.369 & $\mathrm{~s}(p=0.05)$ \\
EM & BR & 0.314 & 0.394 & $\mathrm{~ns}$ \\
PO & CO & $0.124^{*}$ & 0.304 & $\mathrm{~s}(p=0.05)$ \\
PO & CS & $0.113^{*}$ & 0.250 & $\mathrm{~s}(p=0.05)$ \\
CO & CS & 0.480 & 0.306 & $\mathrm{~s}(p=0.05)$ \\
CS & BR & 0.476 & 0.314 & $\mathrm{~s}(p=0.05)$
\end{tabular}

Note: * Not significant paths at $p<0.05$ in the estimated model

Fig 3 


\section{References}

Ahire, S.L. and Golhar, D.Y. (1996), "Quality management in large versus small firms: an empirical investigation", Journal of Small Business Management, Vol. 34 No. 2, pp. 1-13.

Anderson, E.W. and Fornell, C. (1994), "Customer satisfaction, market share, and profitability: findings from Sweden”, Journal of Marketing, Vol. 58 No. 3, pp. 53-66.

Benson, P.G., Saraph, J.V. and Schroeder, R.G. (1991), “The effects of organizational context on quality management: an empirical investigation”, Management Science, Vol. 37 No. 9, pp. 1107-24.

Bergman, B. and Klefsjo, B. (1994), Quality from Customer Needs to Customer Satisfaction, McGrawHill, New York, NY.

Chin, W.W. (1998), "The partial least squares approach to structural equation modeling", in Marcoulides, G.A. (Ed.), Modern Methods for Business Research, LEA, Mahwah, NJ.

Dahlgaard, J., Kristensen, K. and Kanji, G. (1998), Fundamentals of Total Quality Management, Chapman \& Hall, London.

Davenport, T.H. (1993), "Managing in the new world of process", Public Productivity and Management Review, Vol. 18, pp. 133-47.

Dean, J.W. and Bowen, D.E. (1994), "Management theory and total quality: improving research and practice through theory development", Academy of Management Review, Vol. 19 No. 3, pp. 392-418.

Edvardsson, B., Johnson, M.D., Gustafsson, A. and Strandvik, T. (2000), "The effects of satisfaction and loyalty on profits and growth - products versus services", Total Quality Management Journal, Vol. 11 No. 7, pp. 917-27.

Efron, B. and Tibshirani, R.J. (1993), An Introduction to the Bootstrap, Chapman \& Hall, London.

Frei, F.X., Kalakota, R., Leone, A.J. and Marx, L.M. (1999),"Process variation as a determinant of bank performance: evidence from the retail banking study", Management Science, Vol. 45, pp. 1210-20.

Frohlich, M.T. (2002),"Techniques for improving response rates in OM survey research", Journal of Operations Management, Vol. 20, pp. 53-62.

Gustafsson, A. and Johnson, M.D. (1997), "Bridging the quality-satisfaction gap", Quality Management Journal, Vol. 4, pp. 27-43.

Hackman, J.R. and Wageman, R. (1995), "Total quality management: empirical, conceptual, and practical issues” ,Administrative Science Quarterly, Vol. 40, pp. 309-42.

Hellsten, U. and Klefsjo " , B. (2000), "TQM as a management system consisting of values, techniques, and tools” , The TQM Magazine, Vol. 12 No. 4, pp. 238-44.

Hendricks, K.B. and Singhal, V.R. (1997), "Does implementing an effective TQM program actually improve operating performance? Empirical evidence from firms that have won quality awards ”, Management Science, Vol. 43, pp. 1258-74.

Hendricks, K.B. and Singhal, V.R. (2001), "Firm characteristics, total quality management, and financial performance” , Journal of Operations Management, Vol. 19, pp. 269-85.

Hulland, J. (1999), "Use of partial least squares (PLS) in strategic management research: a review of four recent studies", Strategic Management Journal, Vol. 20, pp. 195-204.

laffaldano, M.T. and Muchinsky, P.M. (1985),"Job satisfaction and job performance: a meta analysis” , Psychological Bulletin, Vol. 97, pp. 251-73. 
Ittner, C.D. and Larcker, D.F. (1996), "Measuring the impact of quality initiatives on firm financial performance", in Fedor, D.B. and Ghosh, S. (Eds), Advances in the Management of Organizational Quality, JAI Press, London.

Ittner, C.D. and Larcker, D.F. (1997), "The performance effects of process management techniques” , Management Science, Vol. 43, pp. 522-34.

Johnson, M.D. (1998), Customer Orientation and Market Action, Prentice-Hall, Englewood Cliffs, NJ.

Johnson, M.D. (2001), "Customer satisfaction", in Smelser, N.J. and Baltes, P.B. (Eds), International Encyklopedia of the Social and Behavioral Sciences, Elsevier, Amsterdam.

Johnson, M.D. and Gustafsson, A. (2000), Improving Customer Satisfaction, Loyalty and Profit: An Integrated Measurement and Management System, Jossey-Bass, San Francisco, CA.

Kohli, A.K. and Jaworski, B.J. (1990), "Market orientation: the construct, research propositions, and managerial implications", Journal of Marketing, Vol. 54, pp. 1-18.

Kroslid, D. (1999), In Search of Quality Management - Rethinking and Reinterpretating, Dissertation No. 590, Division of Quality Technology and Management, Linkoping University, Linkoping.

Lemak, D.J. and Reed, R. (2000), "An application of Thompson's typology to TQM in service firms", Journal of Quality Management, Vol. 5, pp. 67-83.

Narver, J.C. and Slater, S.F. (1990),"The effect of a market orientation on business profitability", Journal of Marketing, Vol. 54, pp. 20-35.

Powell, T.C. (1995),"Total quality management as competitive advantage: a review and empirical study", Strategic Management Journal, Vol. 16 No. 1, pp. 15-37.

Raymond, L., Bergeron, F. and Rivard, S. (1998), “Determinants of business process reengineering success in small and large enterprises: an empirical study in the Canadian context", Journal of Small Business Management, Vol. 36 No. 1, pp. 72-84.

Steenkamp, J.E.M. and van Trijp, H.C.M. (1996), "Quality guidance: a consumer-based approach to food quality improvement using partial least squares", European Review of Agricultural Economics, Vol. 23, pp. 195-215.

Wold, H. (1982),"Systems under indirect observation using PLS", in Fornell, C. (Ed.), Second Generation of Multivariate Analysis Methods, Praeger, New York, NY. 